\title{
Temperature and Wind Distribution Effects on Wind Energy Production in Adrar Region (Southern Algeria)
}

\author{
Miloud Benmedjahed*, Abdeldjalil Dahbi, Abdelkader Hadidi, Samir Mouhadjer
}

Unite de Recherche en Energies Renouvelables en Milieu Saharien, Centre de Développement des Energies Renouvelables, URERMS, CDER, Adrar 01000, Algeria

Corresponding Author Email: m_benmedjahed@urerms.dz

https://doi.org/10.18280/ijsdp.160808

Received: 12 October 2021

Accepted: 17 November 2021

\section{Keywords:}

wind, temperature, air density, wind turbine, wind energy

\begin{abstract}
The hottest transitions occur in the summer, as we notice during this period the peak of electricity consumption in Adrar, where the electricity network must use all kinds of energy, especially the wind energy produced by Cabertein wind farm. We evaluated the effect of temperature and wind distribution on the energy produced by one of Gamesa G52 wind turbines, and this was done by studying the wind distribution and determining the number of hours per year according to five cases. Finally, to estimate the monthly produced energy, we used a logical temperature equation, and then we determined the seasonal and annual energy. Low winds are the only reason why wind turbines are unable to produce electricity for a monthly period ranging from 152 An hour (May) to 274 hours (September), meaning that the seasonal production stop, for this reason, ranges between 590 hours (spring) and 779 hours (summer), with an average of 2736 hours per year, while temperatures did not constitute an obstacle to electricity production except. In three months for a short period of 2 hours (June and July) and 22 hours (August), affecting production in the summer season, with an estimated time of 26 hours.
\end{abstract}

\section{INTRODUCTION}

The Adrar region is located in the southwest of Algeria, more than $1200 \mathrm{~km}$ from Algiers. It is located between the meridians: $2^{\circ} \mathrm{E}$ and $6^{\circ} \mathrm{W}$, and the parallels: $20^{\circ} \mathrm{N}$ and $32^{\circ} \mathrm{N}$. Its total area is $427.948 \mathrm{~km}^{2}$, or about $18 \%$ of the total area of Algeria, is bounded from the north by Western Grand Erg and from the south by the Tinzoft plateau. East of the Tademait plateau and west by Erg Chech $[1,2]$, the climate of this region is desert. According to the Classification of Köppen BWh [3], the desert climate characterized by an extreme dryness with rare and weak precipitations, very hot heats with excessively high temperatures during a more or less long period, a very strong solar irradiation with a record duration of sunshine in a large part as well as very low humidity.

Algeria has launched an ambitious program to develop renewable energies and energy efficiency, develop inexhaustible resources, and reduce dependence on fossil energy sources. The Adrar region has the largest sources of renewable energies, especially solar and wind energy, and for this, it was not surprising that it was a site for a wind farm. The only one in the country and several photovoltaic centres [4-7].

Photovoltaic energy cannot be relied upon to cover the electricity demand from air conditioners in the summer, especially from $7 \mathrm{pm}$. Until 4 AM that is why wind energy can be efficient in meeting maximum electricity demand in this season, but this does not mean that this type of energy is not affected by the temperature, as there is a direct effect on the electricity produced from the wind turbine. Each turbine has a temperature field in which it operates, it is, therefore, necessary to choose a wind turbine with specifications appropriate to the nature of the climate. As for the indirect reason, it is the effect of temperature on the density of the air, which decreases with increasing temperature, which means a decrease in the energy produced. However, the wind distribution and wind turbine characteristics still have the most important influence on the energy produced [8].

In this paper, we analyzed the data of temperature, air density, and wind speed at an altitude of 80 meters from the ground [9], so that we were able to determine the wind distribution and calculate the working hours of the wind turbine. Finally, to estimate the monthly produced energy, we used a logical temperature equation, and then we determined the seasonal and annual energy produced by the GAMISA G52 wind turbine.

\section{WIND CHARACTERISTIC}

Weibull distribution is a suitable model for determining the frequency distribution in the studied locations. It is defined by the following equation [10-12]:

$$
f(v)=\frac{k}{C}\left(\frac{v}{C}\right)^{k-1} \exp \left(-\left(\frac{v}{C}\right)^{k}\right)
$$

$\mathrm{f}(\mathrm{v})$ represents the frequency distribution function, $v$ wind speed, $\mathrm{k}$ the shape parameter, and $\mathrm{C}$ scale parameter, likelihood method has been chosen for determining Weibull parameters, in this method, the shape parameter $(\mathrm{k})$ and scale 
parameter $(\mathrm{C})$ is given as [13]:

$$
\begin{gathered}
k=\left[\frac{\sum_{i=1}^{n} v_{i}^{k} \ln \left(v_{i}\right)}{\sum_{i=1}^{n} v_{i}^{k}}-\frac{\sum_{i=1}^{n} \ln \left(v_{i}\right)}{n}\right]^{-1} \\
C=\left[\frac{1}{n} \sum_{i=1}^{n} v^{k}\right]^{\frac{1}{k}}
\end{gathered}
$$

From the collected wind speed every hour, at $80 \mathrm{~m}$ from the ground, The Weibull parameters and the velocity of the studied site were calculated. The monthly, seasonal and annual Weibull parameters are presented in Table 1.

Table 1. Annual, seasonal and monthly distributions at $80 \mathrm{~m}$

\begin{tabular}{|c|c|c|c|c|}
\hline \multicolumn{2}{|c|}{ Distribution } & C & $\mathbf{k}$ & $\bar{v}$ \\
\hline \multirow{10}{*}{$\begin{array}{l}\frac{\lambda}{\Xi} \\
\stackrel{\Xi}{\Xi} \\
\sum\end{array}$} & January & 6.6 & 2.02 & 5.9 \\
\hline & February & 6.9 & 2.06 & 6.2 \\
\hline & March & 7.2 & 2.15 & 6.4 \\
\hline & April & 7.4 & 2.12 & 6.6 \\
\hline & May & 7.8 & 2.33 & 7.0 \\
\hline & June & 6.7 & 1.97 & 6.0 \\
\hline & July & 6.5 & 1.85 & 5.8 \\
\hline & August & 6.3 & 1.92 & 5.6 \\
\hline & September & 6.1 & 1.90 & 5.4 \\
\hline & October & 6.4 & 1.98 & 5.7 \\
\hline \multirow{7}{*}{ 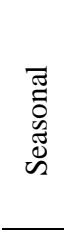 } & November & 6.4 & 2.01 & 5.7 \\
\hline & December & 6.4 & 2.11 & 5.7 \\
\hline & Autumn & 6.7 & 2.18 & 5.9 \\
\hline & Winter & 7.1 & 2.22 & 6.3 \\
\hline & Spring & 7.4 & 2.22 & 6.6 \\
\hline & Summer & 6.9 & 2.16 & 6.2 \\
\hline & Annual & 6.9 & 2.16 & 6.2 \\
\hline
\end{tabular}
from ground

From Table 1, it can be observed that the monthly values of the shape parameter $\mathrm{k}$, varies from 1.85 (July) to 2.33 (May), this means that the distributions are dispersed for five months (June, July, August, September, and October), while the scale parameters C range from $6.1 \mathrm{~m} / \mathrm{s}$ (September) to $7.8 \mathrm{~m} / \mathrm{s}$ (May) and the velocity $\mathrm{v}$ varies from $5.4 \mathrm{~m} / \mathrm{s}$ (September) to $7 \mathrm{~m} / \mathrm{s}$ (May), we also noted that the seasonal distributions are stable for four-season, the Seasonal shape parameter range from 2.16 (Summer) to 2.22 (Winter and Spring), this means that the annual distribution is stable, equal to 2.16. The seasonal scale parameters C range from $6.7 \mathrm{~m} / \mathrm{s}$ (autumn) to $7.4 \mathrm{~m} / \mathrm{s}$ (spring) and the velocity $\mathrm{v}$ varies from $5.7 \mathrm{~m} / \mathrm{s}$ (autumn) to $6.6 \mathrm{~m} / \mathrm{s}$ (spring). As a result, we found that the annual scale parameter equal to $6.9 \mathrm{~m} / \mathrm{s}$ and annual velocity equal to $6.2 \mathrm{~m} / \mathrm{s}$.

\section{WIND TURBINE CHARACTERISTIC}

The Kaberten wind farm is located about $72 \mathrm{~km}$ north of the city of Adrar near a Sonelgaz substation, made up of 12 Gamesa G52 type wind turbines, located on a site with a total area of 33 hectares [14-17]. The project was carried out by two subsidiaries of the Sonelgaz group under the supervision of Cegelec (for the assembly of the equipment). The technical data for wind turbines GAMISA G52 are summarized in Table
2 and the power curve is illustrated in Figure 1 (The information was obtained from EMD International $\mathrm{A} / \mathrm{S}$ WindPro) [18].

Table 2. Wind turbines parameters [18]

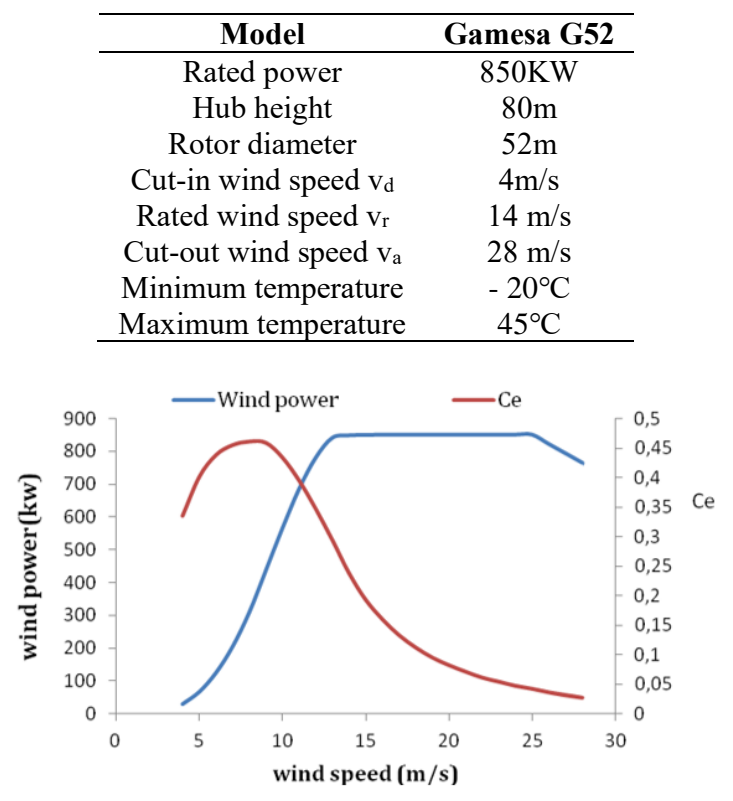

Figure 1. Wind turbine power curve

Form the Wind turbine Characteristic, it can be said that the Gamesa G52 produces electricity in a specific field of winds speed range from $4 \mathrm{~m} / \mathrm{s}$ to $28 \mathrm{~m} / \mathrm{s}$, while the temperature ranges from $-20^{\circ} \mathrm{C}$ to $45^{\circ} \mathrm{C}$, we have five cases that are:

- Case 1: The wind turbine is inactive due to the wind speed $\mathrm{v}<4 \mathrm{~m} / \mathrm{s}$ and $\mathrm{v}>28 \mathrm{~m} / \mathrm{s}$ and temperature $\mathrm{T}<-20^{\circ} \mathrm{C}, \mathrm{T}>45^{\circ} \mathrm{C}$;

- Case 2: The wind turbine is inactive due to the wind speed $\mathrm{v}<4 \mathrm{~m} / \mathrm{s}$ and $\mathrm{v}>28 \mathrm{~m} / \mathrm{s}$ and temperature $-20<\mathrm{T}<45^{\circ} \mathrm{C}$;

- $\quad$ Case 3: Wind turbine is inactive due to wind speed $4 \mathrm{~m} / \mathrm{s} \leq \mathrm{v} \leq 28 \mathrm{~m} / \mathrm{s}$ and temperature $\mathrm{T}<-20^{\circ} \mathrm{C}$, $\mathrm{T}>45^{\circ} \mathrm{C}$;

- $\quad$ Case 4: The wind turbine is active due to the wind speed $4 \mathrm{~m} / \mathrm{s} \leq \mathrm{v}<14 \mathrm{~m} / \mathrm{s}$ and temperature -20 $<\mathrm{T}<45^{\circ} \mathrm{C}$;

- Case5: The wind turbine is active at rated power due to the wind speed $14 \mathrm{~m} / \mathrm{s} \leq \mathrm{v} \leq 28 \mathrm{~m} / \mathrm{s}$ and temperature $-20<\mathrm{T}<45^{\circ} \mathrm{C}$;

We used SKTM database for calculated an hourly distribution for each case. The results are presented in Table 3 .

From Table 3, it can be said that the maximum monthly production time equals 584 hours, recorded in May, as wind turbine can produce electricity at rated power in this month for a period of 7 hours, for another month of production per month range from 444 hours (September) to 546 hours (March), this means that spring is the perfect season for the wind turbine. As the number of hours of turbine production in autumn, winter, spring, and summer are estimated at 1445 hours, 1493 hours, 1599 hours, and 1408 hours respectively. Thus, we obtain an annual average of operating equally to 5944 hours.

We also observed that wind turbines are unable to produce electricity at rated power for November and December, while production time at rated power varies from 1 hour (October) to 6 hours (July), this means that the seasonal time production at a rated power range from 2 hours (Autumn) to 15hour 
(Spring) and annul time equal to 38 hours. However, low winds are the only reason that wind turbines are unable to produce electricity for a monthly period range from 152 hours (May) to 274 hours (September), this means that the cessation of seasonal production, for this reason, ranges between 590 hours (Spring) and 779 hours (Summer), an average of 2736 hours per year, While the temperature did not constitute an obstacle to the production of electricity except in three months for a short period estimated at two hours (June and July) and 22 hours (August), which affects the production in the Summer season, with an estimated time 26 hours, this is the same as the annual rate. As for cases of high temperature that is accompanied by low winds, they range from one hour (June and July) to 14 hours (August), which affects production in the summer season and is also the annual rate (the temperature did not affect production in the other seasons), it is estimated at 16 hours.

Table 3. Monthly, seasonal and annual distribution of hours for different operating cases

\begin{tabular}{|c|c|c|c|c|c|c|}
\hline \multicolumn{2}{|c|}{ Distribution } & Case 1 & Case 2 & Case 3 & Case4 & Case 5 \\
\hline \multirow{11}{*}{ 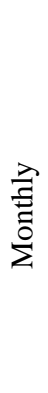 } & January & 0 & 240 & 0 & 500 & 4 \\
\hline & February & 0 & 200 & 0 & 468 & 4 \\
\hline & March & 0 & 194 & 0 & 546 & 4 \\
\hline & April & 0 & 186 & 0 & 529 & 5 \\
\hline & May & 0 & 152 & 0 & 584 & 7 \\
\hline & June & 0 & 229 & 0 & 485 & 4 \\
\hline & July & 2 & 244 & 1 & 458 & 5 \\
\hline & August & 22 & 269 & 14 & 470 & 2 \\
\hline & September & 2 & 274 & 1 & 444 & 2 \\
\hline & October & 0 & 258 & 0 & 486 & 1 \\
\hline & November & 0 & 243 & 0 & 477 & 0 \\
\hline & December & 0 & 247 & 0 & 497 & 0 \\
\hline & Autumn & 0 & 737 & 0 & 1445 & 2 \\
\hline & Winter & 0 & 629 & 0 & 1493 & 14 \\
\hline & Spring & 0 & 590 & 0 & 1599 & 15 \\
\hline & Summer & 26 & 779 & 16 & 1408 & 7 \\
\hline & Annual & 26 & 2736 & 16 & 5944 & 38 \\
\hline
\end{tabular}

$\left\{\begin{array}{l}C_{e}\left(v_{i}\right)=2 \times 10^{-7} v_{i}^{5}-3 \times 10^{-5} v_{i}^{4}+0.0017 v_{i}^{3}-0.0373 v_{i}^{2}+0.3227 v_{i}-0.4696 \text { if } 4 \leq v_{i} \leq 28 \\ C_{e}\left(v_{i}\right)=0\end{array}\right.$

We calculated the average wind energy produced by one wind turbine (Gamesa G52). The monthly average wind energy is shown in Figure 2, while the seasonal and annual wind energy is summarized in Table 4.

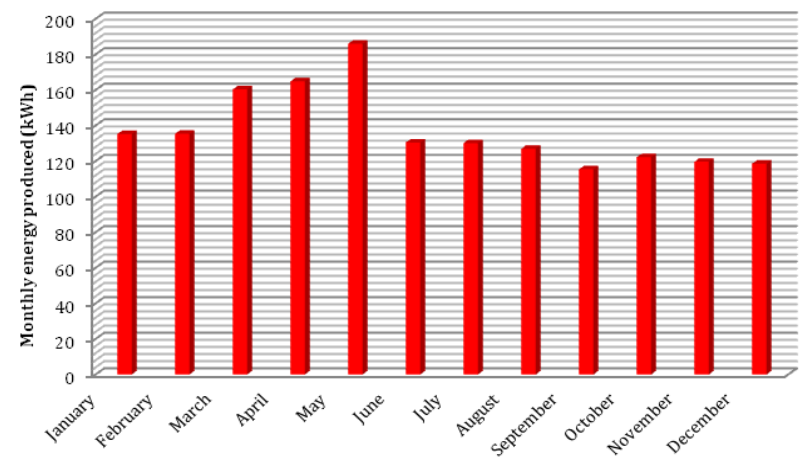

Figure 2. Monthly average wind energy
Finally, it can be said that wind turbines operate most of the year, but they rarely reach rated power, as the total average production hours are estimated at 5982 hours out of 8760 hours in a year, while that the principal reason that affects is low winds, while the temperature affects are limited.

\section{WIND ENERGY}

We used the climatic conditions database for the studied site to estimate the monthly, seasonal and annual electrical energy that it produces for a single wind turbine, this database consists of measurements of temperature, wind speed, and air density at turbine height, it was measured every hour for 12 years (from 2001 to 2013). We took into account the change in temperature and air density for each measurement, so we calculated the average energy produced according to the following equation $[19,20]$ :

$$
E=\frac{\frac{1}{2}\left(\frac{D}{2}\right)^{2} \pi t \sum_{i=1}^{n} \rho_{i} g\left(T_{i}\right) C_{e}\left(v_{i}\right) v_{i}^{3}}{n}
$$

$\mathrm{D}$ and $\mathrm{t}$ respectively represent the wind turbine diameter $(\mathrm{m})$ and period (hours), while $\rho_{i}, T_{i}$ and $v_{i}$ respectively represent the air density $\left(\mathrm{kg} / \mathrm{m}^{3}\right)$, temperature $\left({ }^{\circ} \mathrm{C}\right)$, wind speed $(\mathrm{m} / \mathrm{s})$ for measure $i$, while $n$ is the number of measurements $g\left(T_{i}\right)$ is a logical equation defined as follows [21]:

$$
\left\{\begin{array}{l}
g\left(T_{i}\right)=1 \quad \text { if } \quad-20<T_{i}<45 \\
g\left(T_{i}\right)=0 \quad \text { if } \quad T_{i} \leq-20, T_{i} \geq 45
\end{array}\right.
$$

$\mathrm{C}_{\mathrm{e}}\left(\mathrm{v}_{\mathrm{i}}\right)$ is a polynomial of efficiency, defined by the following equation [11]:
From Figure 2, it can be seen that the Gamesa G52 wind turbine is more productive in May, with average wind energy equal to $185.95 \mathrm{MWh}$. As for the other months, the average monthly wind energy ranges from 115.34 MWh (September) to $164.82 \mathrm{MWh}$ (April). We have noticed that the amount of energy produced has increased steadily from January until it reaches its maximum value in May, and then begins to decline in the following months. This is mainly due to the nature of wind distribution and the characteristics of wind turbines. As for the direct effect of temperature, it cannot be observed.

From Table 4, it can be observed that the energy produced by a wind turbine (Gamesa G52) in the autumn, winter, spring, and summer is estimated respectively at $344.96 \mathrm{MWh}, 425.39$ MWh, 494.88 MWh, and 379.52 MWh. Thus, we obtain annual energy equal to $1644.75 \mathrm{MWh}$. We noticed the decrease in the value of the energy produced in the winter and summer seasons, are the wind distribution characteristics in the two seasons, as the temperature affected the air density in summer, although the stoppage due to the temperature was not recorded except in the summer. 
Table 4. Seasonal and annual energy produced by Gamesa G52 wind turbine

\begin{tabular}{cccccc}
\hline Period & Autumn & Winter & Spring & Summer & Annual \\
\hline Wind energy (MWh) & 344.96 & 425.39 & 494.88 & 379.52 & 1644.75 \\
\hline
\end{tabular}

\section{CONCLUSION}

In this paper, we studied the effect of wind distribution and temperature characteristics by adopting hourly measurements for the period from January 2001 to December 2013 in addition to the characteristics of wind turbines on the production of wind energy for one wind turbine. The results obtained are:

The distributions are dispersed only five months (June, July, August, September, and October), while the scale parameters $\mathrm{C}$ range from $6.1 \mathrm{~m} / \mathrm{s}$ (September) to $7.8 \mathrm{~m} / \mathrm{s}$ (May) and the velocity v varies from $5.4 \mathrm{~m} / \mathrm{s}$ (September) to $7 \mathrm{~m} / \mathrm{s}$ (May), the seasonal distributions are stable for four-season, this means that the annual distribution is stable, the seasonal parameters scale $\mathrm{C}$ range from $6.7 \mathrm{~m} / \mathrm{s}$ (autumn) to $7.4 \mathrm{~m} / \mathrm{s}$ (Spring) and the velocity $\mathrm{v}$ varies from $5.7 \mathrm{~m} / \mathrm{s}$ (autumn) to $6.6 \mathrm{~m} / \mathrm{s}$ (Spring). As a result, we found that the annual scale parameter equal to $6.9 \mathrm{~m} / \mathrm{s}$ and annual velocity equal to $6.2 \mathrm{~m} / \mathrm{s}$.

The maximum monthly production time equals 584 hours, recorded in May, as wind turbines can produce electricity at rated power in this month for 7 hours, while spring is the perfect season for the wind turbine. As the number of hours of wind turbine production in autumn, winter, spring, and summer are estimated at 1445 hours, 1493 hours, 1599 hours, and 1408 hours respectively. Thus, we obtain an annual average of operating equally to 5944 hours.

The temperature did not constitute an obstacle to the production of electricity except in three months for a short period estimated at two hours (June and July) and 22 hours (August), which affects the production in the summer season, with an estimated time of 26 hours, this is the same as the annual rate. As for cases of high temperature that is accompanied by low winds, they range from one hour (June and July) to 14 hours (August), which affects production in the summer season and is also the annual rate (the temperature did not affect production in the other seasons), it is estimated at 16 hours.

The Gamesa G52 wind turbine is more productive in May, with average wind energy equal to $185.95 \mathrm{MWh}$. As for the other months, the average monthly wind energy ranges from 115.34 MWh (September) to 164.82 MWh (April).

The energy produced by a wind turbine (Gamesa G52) in the autumn, winter, spring, and summer is estimated respectively at $344.96 \mathrm{MWh}, 425.39 \mathrm{MWh}, 494.88 \mathrm{MWh}$, and 379.52 MWh. Thus, we obtain annual energy equal to 1644.75 MWh, the characteristics of wind distribution were the reason for the decrease in production in winter, while in summer, in addition to the distribution of winds, the temperature affected the density of the air, and the stoppage due to temperature was recorded only in this season.

\section{ACKNOWLEDGMENT}

I express my deepest thanks to the Kaberten wind farm and SKTM staffs for providing a data base (wind and temperature) and arrange all facilities for the success of the mission. It is my radiant sentiment to put on record my best regards, and my deepest gratitude to all my colleagues at Unité de Recherche en Energies renouvelables en Milieu Saharien, Centre de Développement des Energies Renouvelables, (URERMS) for their precise and precious guidance which has been of great value to my study both in theory and in practice.

\section{REFERENCES}

[1] Callot, Y. (1988). Evolution polyphasee d'un massif dunaire subtropical; le Grand Erg occidental (Algerie). Bulletin de la Société Géologique de France, IV(6): 1073-1079. https://doi.org/10.2113/gssgfbull.IV.6.1073

[2] Petit-Maire, N., Commelin, D., Fabre, J., Fontugne, M. (1990). First evidence for Holocene rainfall in the Tanezrouft hyperdesert and its margins. Palaeogeography, Palaeoclimatology, palaeoecology, 79(3-4): 333-338. https://doi.org/10.1016/00310182(90)90026-4

[3] Peel, M.C., Finlayson, B.L., McMahon, T.A. (2007). Updated world map of the Köppen-Geiger climate classification. Hydrology and Earth System Sciences Discussions, 4(2): 439-473. https://doi.org/10.5194/hess11-1633-2007

[4] Benmedjahed, M., Maouedj, R. (2019). Assessment of Acoustic impact for the wind farm in Algeria. In 2019 1st Global Power, Energy and Communication Conference (GPECOM), $\quad$ pp. 316-320. https://doi.org/10.1109/GPECOM.2019.8778498

[5] Benmedjahed, M., Ghellai, N., Benmansour, A., Boudai, S.M., Hellal, M.A.T. (2014). Assessment of wind energy and energy cost in Algeria. Journal of Renewable Energy and Smart Grid Technology, 9(1): 31-40.

[6] Boudia, S.M., Benmansour, A., Ghellai, N., Benmedjahed, M., Tabet Hellal, M.A. (2012). Monthly and seasonal assessment of wind energy potential in Mechria region, occidental highlands of Algeria. International Journal of Green Energy, 9(3): 243-255. http://dx.doi.org/10.1080/15435075.2011.621482

[7] Benmedjahed, M., Ghellai, N., Bouzid, Z., Chiali, A. (2015). Temporal assessment of wind energy resource in "Adrar" (south of Algeria); calculation and modeling of wind turbine noise. In 2nd International Congress on Energy Efficiency and Energy Related Materials (ENEFM2014), pp. 33-42. https://doi.org/10.1007/9783-319-16901-9_5

[8] Benmedjahed, M., Maouedj, R. Mouhadjer, S. (2017). Wind potential assessment of M'sila in Algerian highlands regions; modeling of wind turbine noise. Energy Procedia, 119: 642-649. https://doi.org/10.1016/j.egypro.2017.07.090

[9] Shariket Kahraba wa Taket Moutadjadida. (2021). https://www.sktm.dz/,/, accessed on May 12, 2021.

[10] Noorollahi, Y., Kalantari, A.S., Saifoddin, A., Yousefi, H. (2021). Distributed wind and solar power for grid sustainability and emission reduction. Environmental Progress \& Sustainable Energy, 40(6): e13686. https://doi.org/10.1002/ep.13686 
[11] Benmedjahed, M., Maouedj, R. (2018). Wind power assessment in Algeria; methods development. In 2018 International Conference on Wind Energy and Applications in Algeria (ICWEAA), pp. 1-6. https://doi.org/10.1109/ICWEAA.2018.8605049

[12] Benmedjahed, M., Maouedj, R. (2018). Technical and economic analysis of wind turbine system for isolated location at Adrar in Algeria. In 2018 6th International Renewable and Sustainable Energy Conference (IRSEC), pp. 1-4. https://doi.org/10.1109/IRSEC.2018.8702948

[13] Sathyajith, M. (2006). Wind Energy: Fundamentals, Resource Analysis and Economics. Springer Science \& Business Media. https://doi.org/10.1007/3-540-30906-3

[14] Louassa, S., Guerri, O., Kaabeche, A., Yassaa, N. (2019). Effects of local ambient air temperatures on wind park performance: Case of the Kaberten wind park. Energy Sources, Part A: Recovery, Utilization, and Environmental Effects, pp. 1-14. https://doi.org/10.1080/15567036.2019.1673509

[15] Mohamed, B., Fadela, B., Mounir, K. (2015). Optimization of the wind turbines location in Kaberten wind farm in Algeria. Energy Procedia, 74: 122-129. https://doi.org/10.1016/j.egypro.2015.07.532

[16] Guerri, O., Dali, A., Boudia, S.M., Yassaa, N. (2020). Performance evaluation of a wind farm using different power density distributions. Energy Sources, Part A: Recovery, Utilization, and Environmental Effects, pp. 113. https://doi.org/10.1080/15567036.2020.1775727

[17] Djamai, M., Merzouk, N.K. (2011). Wind farm feasibility study and site selection in Adrar, Algeria. Energy Procedia, 6: 136-142. https://doi.org/10.1016/j.egypro.2011.05.016

[18] EMD International A/S Windpro 2.8 - EMD International Software. https:/www.emd.dk/windpro/downloads/, accessed on April 15, 2019.
[19] Rosen, K., Van Buskirk, R., Garbesi, K. (1999). Wind energy potential of coastal Eritrea: An analysis of sparse wind data. Solar Energy, 66(3): 201-213. https://doi.org/10.1016/S0038-092X(99)00026-2

[20] Barrois, B. (2017). Methods to evaluate accuracy-energy trade-off in operator-level approximate computing. Doctoral dissertation, Rennes 1. https://www.theses.fr/2017REN1S097.

[21] Wang, D.L. (2008). Solutions of linear logical equations. Computer Engineering and Design, 29(5): 1195-1225.

\section{NOMENCLATURE}

$\begin{array}{ll}\mathrm{C} & \text { scale parameter }(\mathrm{m} / \mathrm{s}) \\ \mathrm{D} & \text { wind turbine diameter }(\mathrm{m}) \\ \mathrm{E} & \text { energy }(\mathrm{KWh}) \\ \mathrm{i} & \text { hourly measure } \\ \mathrm{k} & \text { shape parameter } \\ \mathrm{n} & \text { number total of hourly measure } \\ \mathrm{T} & \text { period (hours) } \\ \mathrm{T}_{\mathrm{i}} & \text { temperature }\left({ }^{\circ} \mathrm{C}\right) \text { for measure } \mathrm{i} \\ \mathrm{v} & \text { wind speed }(\mathrm{m} / \mathrm{s}) \\ \mathrm{V}_{\mathrm{i}} & \text { wind speed at measure } \mathrm{i}(\mathrm{m} / \mathrm{s}) \\ \bar{v} & \text { velocity }(\mathrm{m} / \mathrm{s})\end{array}$

\section{Greek symbols}

$\rho_{\mathrm{i}} \quad$ air density $\left(\mathrm{kg} / \mathrm{m}^{3}\right)$ for measure i

\section{Subscripts}

$\mathrm{C}_{\mathrm{e}}\left(\mathrm{v}_{\mathrm{i}}\right)$ polynomial of wind turbine efficiency

$\mathrm{f}(\mathrm{v}) \quad$ frequency distribution

$\mathrm{g}\left(\mathrm{T}_{\mathrm{i}}\right) \quad$ logical function 